Indonesian Journal of Social Sciences Volume 12 No. 02, July - December 2020, page 34-48

\title{
The influence of social media on social interactions among students
}

\author{
Anna Yohanna \\ Department of Anthropology \\ Faculty of Social and Political Sciences, Universitas Airlangga, Surabaya \\ Address: Jalan Airlangga 4-6 Surabaya, Indonesia \\ E-mail: annayohanna1902@gmail.com
}

\begin{abstract}
Nowadays, students cannot be separated from social media. Every student can have many accounts of social media. Social media itself is one of the students' primary needs, but social media has a significant impact. The purpose of this study is that researchers want to see the positive and negative impacts of social media on the social interactions of its users. Researchers used a qualitative type with a purposive method. Researchers conducted interviews with fourteen students of the Faculty of Social and Political Sciences, Universitas Airlangga. This study indicates that students' social media has positive and negative impacts on students' social interactions with their environment. One of the positive effects of social media is that students get the latest information more easily. Meanwhile, one of the negative impacts is that students become addicted to using social media to not interact with their environment. So, social media positively and negatively influences student interactions at the Faculty of Social and Political Sciences, Universitas Airlangga.
\end{abstract}

Keywords: social media, social interaction, students

\section{Introduction}

Social media in this era of globalization is viral among teenagers in Indonesia. Nowadays, social media is an obligation that teenagers think they must have and have an influence on the lives of today's generation. Today, who does not know social media? Social media's role has become part of human's life, such as the scope of education, both academically and as a chat material for teenagers. It is undeniable, and social media has a considerable influence on someone. Someone who is initially small can become significant because of social media, and vice versa (Putri et al. 2016).

Various kinds of technology created by humans have a function to facilitate human life itself. Some use social media when they need entertainment. Someone who has these feelings usually uses social media to deal with the loneliness experienced due to a lack of direct communication with others (Rosy 2018).

Social media also plays a role in the continuity of students and students in seeking information, news, education, insights, and long-distance contacts. People who use social media are now free to communicate and share information, any news with each other without thinking of obstacles such as cost, distance, and time (Soliha 2015). Distance and time are no longer a problem for today's youth. Many teenagers or students who are traveling far away to study and are far from their parents and families, as well as people who are far from their spouses, besides that, having meetings in the world of work, is not difficult to meet. That convenience is because social media offers many features that do not require face-to-face contact but can bring both parties together remotely. Social media can be a medium for learning entrepreneurship and foster interest in becoming entrepreneurs for teenagers. Lots of young entrepreneurs today have businesses through social media. People who use social media find it easier to buy something without having to go out of the house to shop, but now with just one button, people can order all the items they need or want. The ease of finding various sources is what makes social media a primary need that is always around.

The impact arising from this social disturbance is not only a positive impact that affects the community, but even adolescents are also affected. This incident shows that the virtual world that 
Yohanna: The influence of social media on social interactions among students

occurs in social media is involved in the interpersonal life of adolescents in the real world that they face every day (Baxter et al. 2008). Social media can help problems from all walks of life in finding sources of information. However, it makes people lazy to move about doing activities that they usually do every day.

Social media can also make children who are not old enough to disclose things that they should not be able to see, for example, such as pornography. Another impact of social media is the emergence of cyberbullying of adolescents to others, causing envy because of something their friends are showing off on social media, and so on. The most significant impact of the skyrocketing social media is the lack of social interaction with fellow humans. According to Soekanto (2012), social interaction is a phenomenon of dynamic social relationships between one person and another, one with another group, and groups with other groups.

Many teenagers today tend to play social media without realizing that there will be no more social interaction between them if they are enslaved continuously by social media. Adolescents who have recently become hyperactive in cyberspace on social media tend to show off often their daily lifestyle that does not want to look outdated or scurvy (less up-date) (Putri et al. 2016). According to Neil Postman, technology gives rise to a technopoly culture, a time when people deify technology and technology to regulate all human life (Straubhaar et al. 2012).

According to Broom \& Selznick (1961) in Honigmann (1964), social interaction is a relationship with the awareness of other people around us and responding to others. Broom and Selznic (1961) say, that social interaction is based on the existence of "awareness of other people." However, perhaps the issue of 'awareness' itself has begun to disappear in society, especially teenagers, because social media has been too spoiled (Honigmann 1964).

Budyatna (2005) in Dillow et al. (2006) suggest that the best form of social interaction is the transactional, dynamic, and reciprocal response between the two communicating parties. Budyatna (2005) in Dillow et al. (2006) also explained that the emergence of technology, such as mobile phones, which have many social media features, had influenced the transactional process. Therefore, adolescents need social interaction with each other, because if this teenager does not interact. Humans will always live together, whether they avoid or not avoid, humans will always be related, and always interact with other humans. Teenagers, most of whom are students and college students, are expected to use social media less often and interact more directly with others. If teenagers can also filter whatever is on social media.

Research from Putri et al. (2016) showed that social media does not really represent reality. Teenagers often upload their daily activities to become more popular in their environment, so they don't always show their true social condition. A study by Drakel et al. (2018) shows that social media influences social interaction among FISPOL students of Sam Ratulangi University. Drakel et al. (2018) show that students are more focused on social media when they are in the teaching and learning process, and when they are outside the classroom, there is almost no communication between students. This phenomenon shows that students have unconsciously faced social media's swift influence that can hinder social interaction. Based on this, researchers are interested in researching social media's influence on social interaction and its impact on students of the Faculty of Social and Political Sciences, Universitas Airlangga.

\section{Methods}

This study used qualitative research methods. The qualitative method aims to conduct scientific research with a social context that prioritizes a deep communication process between the researcher and the informant under study (Herdiansyah 2015). Researchers used interview techniques to collect data. Interviewing is a question and answer process between two or more people who use direct physical and 
social contact to determine what the interviewer is looking for (Soegijono 1993). Researchers used a purposive technique to collect data. Researchers choose based on the informants' status, who students currently studying at the Faculty of Social and Political Sciences, Universitas Airlangga.

Researchers conducted interviews with fourteen informants, with seven male informants and seven female informants, on December 4, 2018, at the Faculty of Social and Political Sciences, Universitas Airlangga. The informants came from different departments in the Faculty of Social and Political Sciences, namely the anthropology department, sociology department, information and library science department, political science department, communication science department, public administration science department, and international relations department. Researchers take informants in each department so that the data can be more varied. The following in Table 1 below is about the questions that researcher asks to informants.

Table 1

List of questions for informants

\begin{tabular}{|c|c|}
\hline No. & Question \\
\hline 1 & $\begin{array}{l}\text { Apakah Anda bermain sosial media? Jika iya, sosial } \\
\text { media apa saja yang sering Anda mainkan? } \\
\text { (Do you play social media? If so, what social media } \\
\text { do you play on the most?) }\end{array}$ \\
\hline 2 & $\begin{array}{l}\text { Apa dampak positif dan negatif dari sosial media bagi } \\
\text { Anda? } \\
\text { (What are the positive and negative impacts of social } \\
\text { media on you?) }\end{array}$ \\
\hline 3 & $\begin{array}{l}\text { Menurut Anda, apa saja pengaruh sosial media } \\
\text { terhadap keberlangsungan interaksi sosial antar } \\
\text { mahasiswa? } \\
\text { (In your opinion, what are the effects of social media } \\
\text { on the sustainability of social interaction between } \\
\text { students?) }\end{array}$ \\
\hline 4 & $\begin{array}{l}\text { Sikap apa yang sebaiknya dilakukan dalam } \\
\text { menghadapi derasnya arus sosial media pada zaman } \\
\text { sekarang? } \\
\text { (What attitude should be taken in facing the swift flow } \\
\text { of social media today?) }\end{array}$ \\
\hline
\end{tabular}

\section{Results and Discussion}

All research results were obtained by researchers at the Faculty of Social and Political Sciences at Universitas Airlangga, Surabaya. The following are the interviews with male and female students from the department of communication science, Faculty of Social and Political Sciences, Universitas Airlangga.

\footnotetext{
"Ya. Line, Twitter, WhatsApp, Instagram, Pinterest." (Wawancara dengan mahasiswa laki-laki dari departemen komunikasi).

("Yes. Line, Twitter, WhatsApp, Instagram, Pinterest." (Interviewed with male students from department of communication science)).

"Ya. Instagram, Twitter, Youtube." (Wawancara dengan mahasiswa perempuan dari departemen komunikasi).
} 
Yohanna: The influence of social media on social interactions among students

("Yes. Instagram, Twitter, Youtube." (Interviewed with female students from department of communication science)).

Based on the above interview results, male and female informants from the communication science department indicated that they frequently access their social media, for example, Line, Twitter, Instagram, and others. Apart from students from the communication science department, twelve students from other departments also use social media daily. The following are the interviews with other informants who are students of the Faculty of Social and Political Sciences, Universitas Airlangga.

"Iya. Instagram, Twitter" (Wawancara dengan mahasiswa laki-laki dari departemen hubungan internasional).

("Yes. Instagram, Twitter." (Interview with male students from the department of international relations)).

"Iya. Line, Whatsapp" (Wawancara dengan mahasiswa perempuan dari departemen hubungan internasional).

("Yes. Line, Whatsapp" (Interview with female students from the department of international relations)).

"Iya. Line, Instagram, Twitter, Facebook." (Wawancara dengan mahasiswa laki-laki dari departemen administrasi negara).

("Yes. Line, Instagram, Twitter, Facebook." (Interview with male students from the public administration department)).

"Iya. Line, Whatsapp, IG, Twitter" (Wawancara dengan mahasiswa perempuan dari departemen administrasi negara).

("Yes. Line, Whatsapp, IG, Twitter." (Interview with female students from the public administration department).

"Iya. Instagram" (Wawancara dengan mahasiswa laki-laki dari departemen ilmu politik).

("Yes. Instagram." (Interview with male students from the political science department)).

"Iya. Line, instagram" (Wawancara dengan mahasiswa perempuan dari departemen ilmu politik).

("Yes. Line, instagram" (Interview with female students from the political science department)).

"Iya. Instagram." (Wawancara dengan mahasiswa laki-laki dari departemen antropologi).

("Yes. Instagram." (Interview with male students from the anthropology department)).

"Iya. Line, Twitter." (Wawancara dengan mahasiswa perempuan dari departemen antropologi).

("Yes. Line, Twitter." (Interview with female students from the anthropology department)).

"Iya. Instagram, Line" (Wawancara dengan mahasiswa laki-laki dari departemen sosiologi).

("Yes. Instagram, Line" (Interview with male students from the sociology department)).

"Iya. Instagram, Line, Whatsapp" (Wawancara dengan mahasiswa perempuan dari departemen sosiologi).

("Yes. Instagram, Line, Whatsapp" (Interview with female students from the sociology department)).

"Iya. Line, Whatsapp." (Wawancara dengan mahasiswa laki-laki dari departemen ilmu informasi dan perpustakaan).

("Yes. Line, Whatsapp." (Interview with male students from the information and library science department)).

"Iya. Twitter, Instagram, Tumblr." (Wawancara dengan mahasiswa perempuan dari departemen ilmu informasi dan perpustakaan). 
("Yes. Twitter, Instagram, Tumblr." (Interview with female students from the information and library science department)).

The results of the interview above show that both men and women also use social media. According to male informants, social media has an impact on its users. These impacts are in the form of positive impacts as well as negative impacts. The informant mentioned that in the results of the interview below.

"Positif; memberi banyak informasi, membunuh waktu luang, mempermudah komunikasi. Negatif; mengurangi hal-hal produktif (contoh: belajar), bikin boros kuota, kadang bikin lupa waktu (kalau sudah liat explore instagram), bikin informasi yang masuk kedalam otak bertumpuk-tumpuk gak jelas karena terlalu banyak informasi, mengurangi intensitas interaksi sosial dengan lingkungan." (Wawancara dengan mahasiswa laki-laki dari departemen komunikasi).

("Positive; give a lot of information, kill free time, make communication easier. Negative; reducing productive things (for example: studying), wasteful quota, sometimes forgetting time (if you have seen explore Instagram), making the information that enters the brain pile up unclear due to too much information, reducing the intensity of social interactions with the environment." (Interviewed with male students from department of communication science)).

"Positif: Senang-senang, update Info, inspirasi berkarya. Negatif: Buang-buang waktu. Lupa jam solat, jam makan, kuliah, dsb." (Wawancara dengan mahasiswa laki-laki dari departemen Hubungan Internasional).

("Positive; have fun, update Info, inspiration to work. Negative: Waste of time. Forgetting prayer times, meal times, lectures, and others." (Interview with male students from the Department of International Relations)).

"Positif: Mempermudah mendapatkan informasi. Sebagai sarana hiburan. Negatif: Sejauh ini saya menggunakan sosial media dengan bijak dan tidak berdampak negatif." (Wawancara dengan mahasiswa laki-laki dari departemen Administrasi negara).

("Positive: Make it easier to get information. As a means of entertainment. Negative: So far I have used social media wisely and it has had no negative impact." (Interview with male students from the public administration department)).

"Positif: Mengetahui info-info dan isu dunia terkini. Negatif: Menjauhkan yang dekat. Punya power untuk mempengaruhi sikap dan pandangan seseorang terhadap suatu hal dan hal ini dapat dimanfaatkan oleh oknum-oknum untuk menjatuhkan pihak lain." (Wawancara dengan mahasiswa lakilaki dari departemen ilmu politik).

("Positive: Knowing the latest world information and issues. Negative: Keeping that close. Have the power to influence a person's attitudes and views on something and this can be used by individuals to overthrow other parties." (Interview with male students from the political science department)).

"Positif: Komunikasi lancar. Rekreasi. Negatif: Buang-buang waktu produktif." (Wawancara dengan mahasiswa laki-laki dari departemen antropologi).

("Positive: Smooth communication. Recreation. Negative: Waste of productive time." (Interview with male students from the anthropology department)).

"Positif: Mendapat informasi lebih cepat dan jangkauan informasi yang sangat luas dalam segi wilayah atau materinya. Media komunikasi jarak jauh. Negatif: Waktu kita menjadi sia - sia. Menjadi orang yang malas." (Wawancara dengan mahasiswa laki-laki dari departemen sosiologi).

("Positive: Get information faster and the reach of information is very broad in terms of area or material Long distance communication media. Negative: Our time is wasted. Being lazy." (Interview with male students from the sociology department)). 
Yohanna: The influence of social media on social interactions among students

\begin{abstract}
"Positif: Sarana mencari informasi yang belum kita ketahui, sehingga menjadi sebuah pengetahuan. Sarana tempat berdiskusi dan belajar online. Sarana pekerjaan contohnya menjual suatu barang atau jasa. Sarana komunikasi antar sesama, khususnya kepada yang terbatas jarak. Transaksi jual-beli. Sarana hiburan. Mengaplikasikan dan mempublikasikan bakat. Negatif: Sarana segala kejahatan, mulai dari spionase, hacker, penipuan, pembullyan, hoax, dan menjembatani bocoran soal ujian. Masyarakat tidak memandang etis tidaknya contohnya seperti gaya berbusana. Sarana berkumpulnya paham-paham intoleran atau radikalisme, pemberontakan atau terorisme" (Wawancara dengan mahasiswa laki-laki dari departemen ilmu informasi dan perpustakaan).

("Positive: Means of finding information that we don't know yet, so that it becomes knowledge. A place for online discussion and learning. Means of work for example selling a good or service. Means of communication between people, especially those with limited distances. Buying and selling transactions. Means of entertainment. Apply and publicize talents. Negative: Means of all crimes, ranging from espionage, hackers, fraud, bullying, hoaxes, and bridging exam question leaks. Society does not see ethical or not, for example, such as the style of dress. A means for gathering intolerant ideas or radicalism, rebellion or terrorism." (Interview with male students from the information and library science department)).
\end{abstract}

Based on the interview results, it can be seen that social media has both positive and negative impacts on male students. The positive impact that students feel when they use social media is that social media helps them find out the latest information and quickly, get the latest knowledge, communicate with other people more smoothly, and give them pleasure when they are in their spare time. Although it has many positive impacts on users, the male informants above also mentioned the negative impact of social media. For example, it keeps people close, wasting time, forgetting to pray, and becoming a gathering place for radicalism to terrorism. Meanwhile, female informants' opinions from the Faculty of Social and Political Sciences, Universitas Airlangga are as follows.

"Positif; Menambah pengetahuan dalam segala hal dari yang nggak tahu jadi tahu. Punya banyak perspektif. Main media sosial buatku pribadi jadi membuka pikiran dan wawasan jikalau sesama manusia itu punya perspektif yang berbeda. Oleh karena itu disitu aku belajar untuk menghargai perspektif orang yang beda sama aku. Sumber inspirasi, sejujurnya, diumur 20an ini aku sedang mencari jati diri khususnya 'gimana aku pengen menjalani hidup ini'. Nah dari keinginanku itu aku bisa menemukan orang-orang yang expert dibidangnya kayak how to live as minimalist gitu. Negatif; Banyak orang intoleran. Dengan pesatnya teknologi dan media sosial pasti banyak dan hampir semua orang main. Banyak orang yang konservatif dalam hal negatif. Jadi munafik, banyak orang yang berpura-pura bahagia di instagram, dan banyak yang menghabiskan uang hanya untuk dilihat orang di sosial media. Kecanduan dan membuat orang jadi tidak produktif." (Wawancara dengan mahasiswa perempuan dari departemen komunikasi).

("Positive; Increase knowledge in all things from those who don't know to know. Have multiple perspectives. Playing social media for me personally opens my mind and insight if fellow humans have different perspectives. Therefore, there I learned to respect the perspectives of people who are different from me. A source of inspiration. To be honest, in my 20s I was looking for my true self, especially "how do I want to live this life". So from my wish, I can find people who are experts in their fields like how to live as minimalist. Negative; many people are intolerant. With the rapid development of technology and social media, there are definitely many and almost everyone playing. Many people are conservative when it comes to negativity. So hypocritical, many people pretend to be happy on Instagram, and many spend money just to be seen on social media. Addiction and make people unproductive." (Interviewed with female students from department of communication science)).

"Positif: Sebagai sarana mendapatkan informasi. Sebagai sarana hiburan. Negatif: Membuang waktu. Ngabisin kuota." (Wawancara dengan informan mahasiswa dari departemen Hubungan Internasional). ("Positive: As a means of getting information. As a means of entertainment. Negative: Wasting time. Use up your internet quota." (Interview with female students from the Department of International Relations)). 


\begin{abstract}
"Positif: Dengan adanya sosial media kita jadi lebih "up to date" dengan berita nasional maupun internasional. Sekarang ini juga banyak aksi sosial yang dilakukan melalui sosial media seperti penggalangan dana untuk korban bencana \& itu sangat membantu korban karena bantuan jadi lebih cepat didapat \& disalurkan ke pihak mereka. Negatif: Banyak sekali yang dapat kita jelajah di media sosial di waktu yang bersamaan sehingga membuat kita lupa waktu. Sosial media juga bisa membuat kita termakan dengan berita hoax apabila kita menerima berita tersebut tanpa mencari kebenaran dari sumber yang terpercaya." (Wawancara dengan mahasiswa perempuan dari departemen Administrasi negara).
\end{abstract}

("Positive: With social media, we are more "up to date" with national and international news. Nowadays, there are also many social actions carried out through social media such as raising funds for disaster victims \& this is very helpful for victims because assistance is obtained faster \& distributed to their side. Negative: There is so much we can explore on social media at the same time that it makes us forget the time. Social media can also make us consumed with hoax news if we receive the news without seeking the truth from trusted sources." (Interview with female students from the public administration department)).

"Positif: Menambah informasi tentang berita terbaru, lifestyle, dan lain-lain. Negatif: Kecanduan, membuat malas melakukan sesuatu." (Wawancara dengan mahasiswa perempuan dari departemen ilmu politik).

("Positive: Add information about the latest news, lifestyle, and others. Negative: Addiction, makes you lazy to do something." (Interview with female students from the political science department)).

"Positif: Sebagai sarana hiburan dan informasi karena cakupannya luas dan bisa mengetahui semua info yang didalam maupun luar negeri. Negatif: Lupa waktu karena terlalu asik bermain." (Wawancara dengan mahasiswa perempuan dari departemen antropologi).

("Positive: As a means of entertainment and information because it has wide coverage and can find out all information inside and outside the country. Negative: Forgetting time because it's too cool to play." (Interview with female students from the anthropology department)).

"Positif: Mengetahui berbagai informasi yang sedang update. Negatif: Kecanduan." (Wawancara dengan mahasiswa perempuan dari departemen sosiologi).

("Positive: Know a variety of information that is being updated. Negative: Addiction." (Interview with female students from the sociology department)).

"Positif: Berkenalan dengan orang yang tidak satu daerah atau negara lain. kalau dengan negara lain, mampu mengasah wawasan bahasa asing kita. Negatif: Kecanduan. Apatis dengan lingkungan sekitar." (Wawancara dengan mahasiswa perempuan dari departemen ilmu informasi dan perpustakaan).

("Positive: Get acquainted with people who are not in one region or another country. With other countries, we are able to hone our knowledge of foreign languages. Negative: Addiction. Apathy with the surrounding environment." (Interview with female students from the information and library science department)).

The interviews with all-female informants above show that social media has a positive and negative impact on informants. The positive impact that female informants stated was not much different from that of male informants. According to female informants, social media's positive impact is providing the latest information to its users. Informants also stated that they could also get to know people who were far away and get more knowledge because social media provides broad coverage. Like male informants, female informants also stated that social media also had a negative impact, such as addiction, so that they forgot to do other things. Social media addiction influences the social interactions of its users. The following are the opinions of the informants regarding the influence of social media on student social interactions. 
Yohanna: The influence of social media on social interactions among students

"Pengaruhnya banyak dari positif dan negatifnya. Asalkan digunakan dalam hal baik dan tidak berlebihan akan bermanfaat." (Wawancara dengan mahasiswa perempuan dari departemen komunikasi).

("The effects are many of the positives and negatives. As long as it is used in good terms and not excessively it will be beneficial." (Interviewed with female students from department of communication science)).

“Bisa meningkatkan intensitas tapi juga menurunkan. Utamanya kontak secara langsung." (Wawancara dengan mahasiswa perempuan dari departemen Hubungan Internasional).

("Can increase intensity but also decrease. Mainly direct contact." (Interview with female students from the Department of International Relations)).

"Positifnya, interaksi antar mahasiswa bisa meningkat karena kesamaan topik pembicaraan yang kita dapat dari sosial media tersebut. Negatifnya, sosial media bisa menjauhkan kita dengan lingkungan di kehidupan nyata karena kita terfokus pada dunia maya." (Wawancara dengan mahasiswa perempuan dari departemen Administrasi negara).

("The positive thing is that the interaction between students can increase because of the similarity of the topics we get from the social media. The negative thing is, social media can distance us from the environment in real life because we are focused on cyberspace." (Interview with female students from the public administration department)).

"Interaksi antar mahasiswa menjadi menurun. Karena sekarang serba praktis jika menggunakan sosial media. Tidak perlu bertemu cukup vidcall, dll." (Wawancara dengan mahasiswa perempuan dari departemen ilmu politik).

("Interaction between students has decreased. Because now it is completely practical when using social media. No need to meet enough video calls, etc." (Interview with female students from the political science department)).

"Untuk beberapa kasus tekadang mahasiswa dan termasuk semua orang jadi lebih sibuk dengan gadgetnya masing-masing tanpa memperdulikan lawan bicaranya, interaksi sosial yang mereka jalankan jadi kurang intensif dan mereka menjadi lebih aktif di dunia maya." (Wawancara dengan mahasiswa perempuan dari departemen antropologi).

("In some cases, sometimes students and including everyone else become busier with their respective gadgets regardless of the interlocutor, the social interactions they carry out are less intensive and they become more active in cyberspace." (Interview with female students from the anthropology department)).

"Pengaruhnya untuk menjalin hubungan antar jarak jauh." (Wawancara dengan mahasiswa perempuan dari departemen sosiologi).

("The influence is to establish long-distance relationships." (Interview with female students from the sociology department)).

"Interaksi mahasiswa secara tatap muka jadi berkurang, mahasiswa lebih banyak berinteraksi satu sama lain dengan media sosial, bahkan ketika mengerjakan tugaspun banyak yang memilih lewat group chat." (Wawancara dengan mahasiswa perempuan dari departemen ilmu informasi dan perpustakaan). ("Face-to-face student interactions are reduced, students interact more with each other with social media, even when doing assignments, many choose via group chat." (Interview with female students from the information and library science department)).

Based on interviews with seven female informants, it is known that they think that social media has influenced their interactions with their environment. For example, direct interaction is reduced. Some informants think that not all of the social media's influence on student social interactions is reduced because social media can help informants establish long-distance relationships or provide conversation topics. The interviews with female informants at the Faculty of Social and Political Sciences did not appear to be that different from male informants at the same faculty. 
"Tergantung, tapi yang jelas kadang interaksi sosial antar mahasiswa jadi terganggu karena sosial media." (Wawancara dengan mahasiswa laki-laki dari departemen komunikasi).

("It depends, but what is clear is that sometimes social interactions between students are disrupted due to social media." (Interviewed with male students from department of communication science)).

"Sebagian membuat mahasiswa bisa lebih akrab, dulu tidak kenal menjadi kenal, sharing tugas, info." (Wawancara dengan mahasiswa laki-laki dari departemen Hubungan Internasional).

("Some of them make students more familiar, before they did not know, they became acquainted, sharing assignments, information." (Interview with male students from the Department of International Relations)).

"Jelas pengaruhnya mahasiswa akan lebih efektif dan efisien untuk mendapatkan informasi dan juga mengakses buku secara digital." (Wawancara dengan mahasiswa laki-laki dari departemen Administrasi negara).

("Obviously the effect is that students will be more effective and efficient in obtaining information and also accessing books digitally." (Interview with male students from the public administration department)).

"Keberadaan sosial media sangat berpengaruh bagi interaksi sosial antar mahasiswa, khususnya bagi mahasiswa yang ingin memperbanyak relasi, justru akan mempermudah untuk mencapai hal tersebut." (Wawancara dengan mahasiswa laki-laki dari departemen ilmu politik).

("The existence of social media is very influential for social interaction between students, especially for students who want to increase relationships, it will make it easier to achieve this." (Interview with male students from the political science department)).

"Mengurangi interaksi langsung." (Wawancara dengan mahasiswa laki-laki dari departemen antropologi).

("Reducing direct interaction." (Interview with male students from the anthropology department)).

"Pengaruhnya sangat besar karena dengan adanya sosial media mahasiswa dapat berteman dengan orang yg beda jurusan beda fakultas bahkan beda universitas dan saling bertukar informasi yang menguntungkan." (Wawancara dengan mahasiswa laki-laki dari departemen sosiologi).

("The influence is very big because with social media students can make friends with people from different majors from different faculties and even from different universities and exchange beneficial information." (Interview with male students from the sociology department)).

"Menurut saya, tergantung pada setiap individunya terkadang dengan adanya sosial media mahasiswa lebih aktif dalam berinteraksi dengan sesama dikarenakan terpicunya suatu rasa sadar atau mengetahui tentang di balik media sosial ada manfaat apa yang terkandung di dalamnya, dan terkadang pula kebedaradaan sosial media tidak menutup kemungkinan di kehidupan nyata mahasiswa tersebut tidak aktif(diam seribu bahasa), jauh berbeda ketika dia di dalam sosial media yang sangat aktif, begitu pula sebaliknya. Dalam artian ini tergantung pada sifat individunya." (Wawancara dengan mahasiswa lakilaki dari departemen ilmu informasi dan perpustakaan).

("In my opinion, depending on each individual, sometimes with social media, students are more active in interacting with others because it triggers a sense of awareness or knowing that behind social media there are benefits contained in it, and sometimes social media existence does not rule out possibilities in life. It is obvious that the student is not active (silent on a thousand languages), it is much different when he is in very active social media, and vice versa. In this sense it depends on the individual nature." (Interview with male students from the information and library science department)).

Based on the interview results above, it can be seen that male informants agree that social media influences student social interactions. This influence can lead to both positive and negative. The positive influence that the male informant stated was that social media helped students to be able to interact remotely, add relationships, access digital books, and others. However, the informants also 
Yohanna: The influence of social media on social interactions among students

stated that social media's negative influence on student social interactions was reducing the intensity of direct interaction because students tended to focus on their social media. Such negative influences cause students to be less able to interact directly with their surroundings. Based on interviews with informants who are male and female students, it can be seen that social media has influenced their social interactions. The informants also argued about the attitudes students should take so as not to lead to these negative influences. The following are the results of interviews with informants.

\begin{abstract}
"Menurutku, sosial media tidak selamanya akan berdampak buruk tapi sedikit banyaknya deras arus sosial media di era digital seperti sekarang itu memang berdampak sedikit buruk terutama dalam hal berinteraksi dengan lingkungan. Nah sikap yang seharusnya kita ambil adalah lebih bersikap dewasa dalam bersosial media artinya adalah kita harus dapat me-manage diri dan memahami konteks ruang dan waktu dalam hal ini adalah kita harus tahu kapan waktu untuk bermain sosial media dan kapan kita harus berinteraksi dengan lingkungan sosial kita." (Wawancara dengan mahasiswa laki-laki dari departemen komunikasi).

("In my opinion, social media will not always have a bad impact, but to some extent the swift flow of social media in the digital era like now has a slightly bad impact, especially in terms of interacting with the environment. Now the attitude we should take is to be more mature in social media, which means that we must be able to manage ourselves and understand the context of space and time, in this case we must know when to play social media and when we have to interact with our social environment." (Interviewed with male students from department of communication science)).
\end{abstract}

"Kenali dirimu sendiri, jangan memaksakan, harus punya pikiran terbuka, dasar yang ada dalam dirinya diperkuat. Contoh kayak agama dll." (Wawancara dengan mahasiswa perempuan dari departemen komunikasi).

("Know yourself, don't push, must have an open mind, the foundation that is in him is strengthened. Examples like religion etc." (Interviewed with female students from department of communication science)).

"Jangan anti dengan sosial media, cukup bijak saja dalam menggunakanya dan pandai menfilter apa yg ada didalamnya. Jangan sampai kemudian ssebagai mahasiswal aktor intelektual termakan dengan citra yang ditampilkan di sosmed. Harus cerdas dalam menyikapinya." (Wawancara dengan mahasiswa lakilaki dari departemen Hubungan Internasional).

("Don't be anti-social media, just be wise in using it and clever at filtering what's in it. Do not become consumed by the image displayed on social media as a student / intellectual actor. Must be smart in responding to it." (Interview with male students from the Department of International Relations)).

"Harus bijaksana dan sebaiknya tidak terlalu bergantung terhadap gadget." (Wawancara dengan mahasiswa perempuan dari departemen Hubungan Internasional).

("Must be wise and should not rely too much on gadgets." (Interview with female students from the Department of International Relations)).

"Lebih bisa mengontrol diri, jangan sampai sosial media menghalangi interaksi antar mahasiswa." (Wawancara dengan mahasiswa laki-laki dari departemen Administrasi negara).

("You can control yourself more, don't let social media get in the way of interaction between students." (Interview with male students from the public administration department)).

"Kita harus bisa berfikir kritis terhadap apa yang kita dapat di sosial media. Ada berita, cek sumbernya terpercaya atau tidak. Sekalipun dari sumber terpercaya juga tetep harus hati hati dalam menangkap berita. Selain itu juga harus bisa menahan diri dalam memberikan komentar di sosial media. Kebebasan berpendapat memang diperbolehkan tapi harus sesuai juga dengan ketetapan ketetapan yang diberikan dalam UU ITE." (Wawancara dengan mahasiswa perempuan dari departemen Administrasi negara).

("We must be able to think critically about what we get on social media. There is news, check the source is reliable or not. Even if it is from a trusted source, you have to be careful in catching the news. Besides that, you must also be able to refrain from commenting on social media. Freedom of opinion is 
permissible, but it must also comply with the provisions provided in the ITE Law." (Interview with female students from the public administration department)).

"Tetap harus mampu untuk memilah segala input, agar outputnya tidak justru memberikan dampak yang buruk bagi diri sendiri dan lingkungan terdekat." (Wawancara dengan mahasiswa laki-laki dari departemen ilmu politik).

("We still have to be able to sort out all the inputs, so that the output does not have a bad impact on oneself and the immediate environment." (Interview with male students from the political science department)).

"Gunakan sosial media dengan bijak. Buang yang negatif, petik yang positif. Cari alternatif lain selain sosial media untuk mencari informasi, contohnya: koran, majalah, tv, radio, pamflet, dll. Dan jadikan sosial media sebagai alternatif terakhir." (Wawancara dengan mahasiswa perempuan dari departemen ilmu politik).

("Use social media wisely. Remove the negative, pick the positive. Look for alternatives to social media to find information, for example: newspapers, magazines, TV, radio, pamphlets, etc. And make social media the last alternative." (Interview with female students from the political science department)).

“Mengatur penggunaan waktu dengan baik." (Wawancara dengan mahasiswa laki-laki dari departemen antropologi).

("Manage the use of time well." (Interview with male students from the anthropology department)).

"Harus pintar-pintar memilih sosial media dan konten yang ada di dalamnya, sebenarnya sosial media juga bisa dijadikan sarana belajar yang asik namun hal itu tergantung kepada penggunanya. Jangan gampang termakan isu atau berita yang belum valid sosial media, karena setiap orang bebas berbicara didalamnya jadi kita tidak tahu apakah hal yang dikatakannya benar atau tidak. Jangan menjadikan sosial media sebagai tempat pelarian dlm menghindari beban di dunia nyata. Harus pintar-pintar dan cermat dalam mengatur waktu penggunaan sosial media, agar tidak kecanduan setiap saat." (Wawancara dengan mahasiswa perempuan dari departemen antropologi).

("You have to be smart in choosing social media and the content in it, actually social media can also be used as a fun learning tool, but it depends on the user. Don't be easily consumed by issues or news that are not valid on social media, because everyone is free to speak in it so we don't know whether what they say is true or not. Don't make social media an escape from the burdens of the real world. Must be smart and careful in managing the time to use social media, so as not to get addicted all the time." (Interview with female students from the anthropology department)).

"Kita tidak boleh terlalu bergantung dengan sosial media sebaiknya kita melakukan interaksi secara langsung tanpa menggunakan media/alat komunikasi tersebut. Kita juga harus membatasi pemakaian sosial media dan tau kewajiban kita sebaga pelajar yaitu untuk mencari ilmu bukan mencari hal2 yang tidak perlu seperti gosip, berita hoax atau semacamnya kita juga harus bisa menyaring kata2 dalam berkomentar di sosmed." (Wawancara dengan mahasiswa laki-laki dari departemen sosiologi).

("We must not be too dependent on social media, we should interact directly without using the media / communication tools. We also have to limit the use of social media and know our obligations as students, namely to seek knowledge, not looking for unnecessary things such as gossip, hoax news or the like, we must also be able to filter out the words in comments on social media." (Interview with male students from the sociology department)).

“Mengontrol intensitas dalam menggunakan sosial media." (Wawancara dengan mahasiswa perempuan dari departemen sosiologi).

("Control the intensity in using social media." (Interview with female students from the sociology department)).

"Yang paling penting adalah pemahaman tentang informasi di dalam derasnya arus sosial media, membuat semua masyarakat memiliki akses dan kesempatan yang sama dalam mengaksesnya. Sebagai konsumen kita seharusnya dapat menyaring berita/informasi yang akan kita terima/kita akses dan membagikan kepada siapapun. Kita jangan hanya senantiasa menggunakan gatekeeper atau 
Yohanna: The influence of social media on social interactions among students

gatekeeping (penyeleksi informasi atau suatu kelompok atau individu yang memantau), kita harusnya bisa menjadi bagian darinya, sangat perlu menumbuhkan rasa kesadaran, dan rasa akan memilahmilih, sehingga informasi sesat dapat berkurang." (Wawancara dengan mahasiswa laki-laki dari departemen ilmu informasi dan perpustakaan).

("The most important thing is an understanding of information in the swift flow of social media, making all people have equal access and opportunities to access it. As consumers we should be able to filter the news / information that we will receive / access and share with anyone. We should not only always use gatekeepers or gatekeeping (information selectors or a group or individual monitoring), we should be able to be part of it, really need to cultivate a sense of awareness, and a sense of sorting, so that misleading information can be reduced." (Interview with male students from the information and library science department)).

"Lebih bisa mengontrol diri, jangan sampai sosial media menghalangi interaksi antar mahasiswa." (Wawancara dengan mahasiswa perempuan dari departemen ilmu informasi dan perpustakaan).

("You can control yourself more, don't let social media get in the way of interaction between students." (Interview with female students from the information and library science department)).

Based on the results of the interview, it can be seen that one important thing that students must have in order not to fall into the negative influence of social media is to be able to control themselves and their minds so as not to experience addiction to social media. Social media that provides the latest information also does not fully provide good news; therefore, students need to control themselves and their thoughts to experience these bad influences.

Social media has become one of the primary needs of society. This happens because social media has a function that makes it easy for people to connect without being limited by space and time (Drakel et al. 2018). As students, students also need social media to connect with other students and lecturers so that social media has an important role in fulfilling needs. Based on the results of interviews, the majority of informants have their social media accounts. Based on information from interviewed informants, on average, they use social media Instagram and Line. Instagram is a social media application made to take photos, provide digital filters, or there are effects, and share them so that their followers can see and like them (Innova 2016). The Instagram application began to boom among people around 2014. The majority of Instagram users at that time were junior high school, high school, and university students, but now, from toddlers to parents also have accounts, so this incident has become an obligation for them to have a personal Instagram account. At the same time, the Line application is an instant messenger based application, who uses telephone numbers as a forum to communicate with each other (Fauzan et al. 2016). Line started to skyrocket since 2013, an era after the Blackberry Messenger application. Everyone now loves the Line application itself because of the interests of work, tasks, and especially instant communication between people. Based on the impact given by social media, social media can make it easier for people to get information and the latest news that is currently being discussed.

According to Malik \& Rafiq (2016), the positive impact of social media is expanding friendship, information media, a place to develop skills, and opportunities to interact with people who have social anxiety. Social media can make it easier to find information, buy and sell transactions, and a means for discussion or online learning. All information, from weather news, disasters, sports, to entertainment. The public can find out from the social media they have. The public can obtain information about raising funds to help victims of natural disasters and participate in helping victims of the disaster, such as sending money or simply continuing to share such information. Besides, social media's function is to obtain information, and social media can also facilitate a person's communication over long distances. Communication is the process of conveying messages with the intent and purpose of telling something (Effendy 2000). 
Today, if someone wants to meet or promise something, someone can use social media to agree on something. Social media can also expand one's network of friends with other people. A person can get to know other people both from outside the city or from abroad. Besides being able to increase relationships, social media also provides benefits in increasing knowledge of foreign languages and confidence in communicating directly with strangers. Social media also opens our minds that not everyone thinks the same as us, and makes us realize that we must respect the different perspectives of these people. Some people apply social media to publicize their talents and interests. Besides that, like humans, they need entertainment in their life. Many use social media to get entertainment only to get out of the zone for work, school affairs, and other matters.

In the research of Demetrovics et al. (2008), that often use of the internet or social media can lead to decreased performance at work, sleep irregularly, decreased appetite, and a reduced interest in social interaction with the surrounding environment. Besides, playing social media also causes an addictive effect. Addiction is the behavior of a person who cannot control his desires and negatively impacts himself (Yuwanto 2013).

In Leung's (2004) research, social media addiction is part of managing time. Internet addicts or social media do not realize that they are addicted and do not want to be called internet addicts because they do not feel they are (Widiana et al. 2004). Besides addiction, social media also can change a person's attitude or viewpoint on something caused by irresponsible individuals. Social media can also be the source of all the crimes that have occurred recently. Not a few crimes are committed by social media actors today, for example, hoaxes. Hoaxes are attempts by fraudsters who already know that the news is not valid but are still shared with readers or listeners to deceive or outwit (Rahadi 2017). Social media can also be a place for people to highlight unethical clothing styles in Indonesian society. Many Indonesian clothing styles are more westernized, which is not following the dress culture in Indonesia. Likewise, its effect reduces the intensity of social interaction between students.

In this research, social media has a positive and negative impact on students of the Faculty of Social and Political Sciences, Universitas Airlangga. The positive impact of social media itself is closely related to social media's main function as a communication technology. Students at FISIP need social media to get the latest information and make it easier for students to interact with other students indirectly. Therefore, social media can also make FISIP students care less about their surroundings because they focus on their social media. The negative impact of social media on the research results is that informants say that social media can waste productive time, such as studying, wasting a lot of data packet quotas, and keeping close people away. Social media positively and negatively impacts students and influences their social interactions with the surrounding environment. This influence can occur because of the impact from within students to affect their interactions with the surrounding environment.

According to Soekanto (2012), social interaction is a factor, especially in the relationship between two or more individuals that influence each other. Therefore social interaction is the primary key in social life, and there will be no coexistence if there is no social interaction. Social interaction occurs because humans are social beings whom each need other humans to survive and carry out other activities (Widodo \& Pratitis 2013). Social interaction is an individual relationship with other individuals that are influencing, and there is a reciprocal relationship (Walgito 2010). It is this reciprocal relationship that has rarely appeared among students. Students who should have more direct contact with each other to discuss, do joint assignments, are even busy playing social media on their own.

Students become apathetic towards their surroundings. Many of the real-life that can be found every day, students who are busy gathering in a hangout, but each individual is busy playing social media. There is no more direct social interaction that occurs between them. The initial goal, which was discussing or just chatting together, was hampered because each one was busy with his social media. Students are more concerned with virtual life in their social media than having to interact directly with the real world in front of them. In this study, informants as students said that social media had 
Yohanna: The influence of social media on social interactions among students

influenced their social interactions with the environment. Social media has helped students build relationships with other people that are not easy for these students to meet. Also, students can have broader and up-to-date knowledge so that they can discuss topics on social media when they meet other people. Even so, the bad influence of social media on student social interactions will still exist.

The appropriate attitudes in facing the current flow of social media include having to be able to control the playing of social media, and distinguish which ones are priorities and which are not priorities. Priority in the KBBI (no date) is something that takes precedence and priority over others. Humans must know what they should prioritize, not vice versa, and also have to know when and where to play social media. According to the informant, students must also be able to find out and sort information from social media. Students must be able to think critically first after filtering information, not swallowing it raw. Do not interfere with the social interactions that should occur among students. The ideal social interaction is a direct social interaction that allows individuals and other individuals to come face to face and make physical contact

\section{Conclusion}

Based on the research results, social media's influence on student social interactions is quite significant, both positive and negative. Social media makes it easy for students, especially FISIP students, to find information and make it easier to communicate. Social media can also hinder social interaction between FISIP Universitas Airlangga students. The obstruction of this social interaction is that most of the students do not see the situations and conditions in using social media; most of them focus more on their social media than on the direct social interactions that are happening in front of them. Based on this research, FISIP Universitas Airlangga students should be able to have an attitude that is more able to control the intensity of playing social media and prioritizes direct social interaction rather than using social media.

\section{References}

Baxter R, Hastings N, Law A, \& Glass EJ (2008) A rapid and robust sequence-based genotyping method for BoLA-DRB3 alleles in large numbers of heterozygous cattle. Animal Genetics 39 (5): 561-563.

Demetrovics Z, Szeredi B, \& Rózsa S (2008) The three-factor model of internet addiction: The development of the Problematic Internet Use Questionnaire. Behavior Research Methods 40 (2): 563-574.

Dillow MR, Morse CR, \& Afifi WA (2008) Romantic Reconciliation as Influenced by Implicit Theories of Relationships and Information Seeking Style. Human Communication 11 (3): 349-358

Drakel WJ, Pratiknjo MH, \& Mulianti T (2018) Perilaku Mahasiswa dalam Menggunakan Media Sosial di Universitas Sam Ratulangi Manado. HOLISTIK XI (21A): 1-20.

Effendy OU (2000) Ilmu, Teori dan Filsafat Komunikasi. Bandung: PT. Citra Aditya Bakti.

Fauzan A, Riadi I, \& Fadlil A (2016) Analisis Forensik Digital Pada Line Messenger Untuk Penanganan Cybercrime. Annual Research Seminar (ARS) 2 (1): 159-163.

Herdiansyah H (2015) Metodologi Penelitian Kualitatif Untuk Ilmu Psikologi. Jakarta: Salemba Humanika.

Honigmann JJ (1964) Sociology: A Text with Adapted Readings: Leonard Broom and Philip Selznick. American Anthropologist 66 (2): 486-487.

Innova EI (2016) Motif dan Kepuasan Pengguna Instagram di Komunitas Instameet Indonesia. Jurnal E-Komunikasi 4 (2): 1-11.

KBBI (no date) Kamus Besar Bahasa Indonesia V.

Leung L (2004) Net-generation attributes and seductive properties of the internet predictors of online activities and internet addiction. Cyberpsychology \& Behavior 7 (3): 333-348. 
Malik AU \& Rafiq N (2016) Exploring the relationship of personality, loneliness, and online social support with interned addiction and procrastination. Pakistan Journal of Psychological Research 31 (1): 93-117.

Putri WSR, Nurwati N, \& Santoso MB (2016) Pengaruh Media Sosial Terhadap Perilaku Remaja. In: Prosiding Penelitian dan Pengabdian kepada Masyarakat 3 (1): 47-51.

Rahadi DR (2017) Perilaku Pengguna dan Informasi HOAX di Media Sosial. Jurnal Manajemen \& Kewirausahaan 5 (1): 58-70.

Rosy B (2018) Schoology, Changing A Negative Thinking Pattern About Use of Social Media. Indonesian Journal of Informatics Education 2 (1): 1-6.

Soegijono KR (1993) Wawancara Sebagai Salah Satu Metode Pengumpulan Data. Media Penelitian dan Pengembangan Kesehatan III (01): 17-21.

Soekanto S (2012) Sosiologi Suatu Pengantar. Jakarta: Raja Grafindo Persada.

Soliha SF (2015) Tingkat Ketergantungan Pengguna Media Sosial dan Kecemasan Sosial. Jurnal Interaksi 4 (1): 1-10.

Straubhaar J, LaRose R, \& Davenport L (201) Media Now: Understanding Media, Culture, and Technology Seventh Edition. Wadsworth: Cengage Learning.

Walgito B (2010) Pengantar Psikologi Umum. Yogyakarta: Andi Offset.

Widiana HS, Retnowati S, \& Hidayat R (2004) Kontrol Diri dan Kecenderungan Kecanduan Internet. Humanitas: Indonesian Psychologocycal Journal 1 (1): 6-16.

Widodo AS \& Pratitis NT (2013) Harga Diri Dan Interaksi Sosial Ditinjau Dari Status Sosial Ekonomi Orang Tua. Persona: Jurnal Psikologi Indonesia 2 (2): 131-138.

Yuwanto L (2013) Pengembangan Alat Ukur Blackberry Messenger Addict. In: Proceeding PESAT (Psikologi, Ekonomi, Sastra, Arsitektur \& Teknik sipil) Peningkatan Daya Saing Bangsa Melalui Revitalisasi Peradaban, 8 - 9 Oktober 2013, Depok. Depok: Lembaga Penelitian Universitas Gunadarma 61-70. 